\title{
Profilul etiologic şi clinic al meningitelor infecțioase internate în Spitalul Clinic de Boli Infecțioase şi Tropicale „Dr. Victor Babeş“, Bucureşti
}

\author{
Emanoil Ceauşu', Simin-Aysel Florescu' ${ }^{1}$, Maria Nica', Sebastian Smădu², \\ Daniel Codreanu' ${ }^{2}$, Corina Oprişan ${ }^{2}$, Ana Maria Dascălu' ${ }^{2}$, Cristiana Oprea ${ }^{1}$, \\ Ştefan Lazăr ${ }^{1}$, Corneliu Popescu', Alma Kosa ${ }^{2}$, Petre I. Calistru ${ }^{1}$ \\ ${ }^{1}$ Disciplina Boli Infecţioase II, Universitatea de Medicină şi Farmacie „Carol Davila“, Bucureşti, România \\ ${ }^{2}$ Spitalul Clinic de Boli Infecţioase şi Tropicale „Dr. Victor Babeş“, Bucureşti, România
}

\begin{abstract}
REZUMAT
Meningitele infecţioase sunt afecţiuni severe cu evoluţie rapid nefavorabilă în cazul întârzierii aplicării tratamentului corect.

Obiective. Prezentarea aspectelor clinice şi paraclinice (laborator) ale pacienţilor suspectaţi de meningită, internaţi în perioada 2014-2017 la Spitalul Clinic de Boli Infecţioase şi Tropicale „Dr. V. Babeş“.

Metode. Au fos incluşi în studiu pacienţii care prezentau semne şi simptome de meningită acută conform definiţiei de caz. Valorile clinice şi paraclinice au fost înregistrate într-o bază de date care ulterior a fost prelucrată statistic pentru identificarea diferenţelor semnificative statistic între grupul infirmat şi grupul celor confirmaţi de meningită şi între diferitele subgrupuri din cadrul celor confirmaţi de meningită.

Rezultate. Dintre cele 96 de cazuri de meningite infecţioase confirmate, 53 (54\%) de cazuri au fost virale, $31(32 \%)$ bacteriene, 12 cazuri de meningită tuberculoasă, 1 caz de meningită fungică. Au fost identificate diferenţe semnificative statistic între variabilele clinice şi paraclinice şi etiologia meningitei.
\end{abstract}

Cuvinte cheie: meningita, diagnostic diferenţial, puncţie lombară

\section{INTRODUCERE}

Infecțiile sistemului nervos central, indiferent de etiologia lor (virală, bacteriană, fungică), rămân o cauză importantă de morbiditate şi mortalitate. Într-un studiu observaţional asupra cauzelor mortalității în spitalul nostru, pe o perioadă de 2 ani, am înregistrat o mortalitate de $11,8 \%$ din cauza infecțiilor sistemului nervos central (1). Sechelele meningitelor variază în funcție de etiologie şi vîrstă, cele mai frecvente fiind cele din sfera auditivă, întâlnite cu precădere după meningita pneumococică (până la 30\% dintre pacienți rămân cu sechele auditive) şi, mai rar, deficiențele motorii, epilepsia sau retardul psihic (3-4\% dintre pacienți) (2).

Etiologia meningitelor infecțioase este bacteriană, virală, fungică sau parazitară. În cazul meningitei acute bacteriene, diagnosticul rapid şi instituirea precoce a tratamentului scad semnificativ riscul decesului şi al complicaţiilor ulterioare. Meningita virală beneficiază de tratament etiologic numai în cazul infecției cu virusuri herpetice, în toate celelalte etiologii tratamentul este doar patogenic şi simptomatic (3). 
Algoritmul suspiciunii de meningită la copii şi adulți constă în realizarea urmatorilor paşi (4):

1. Examinarea clinică, care identifică semne şi simptome indicatoare de meningită.

2. În cazul unei suspiciuni de meningită acută, se face puncția lombară pentru obținerea lichidului cefalorahidian (LCR), care va fi analizat inițial la locul recoltării (aspect limpede sau tulbure) şi ulterior în laborator pentru a decela prezența leucocitelor, hematiilor, proteinelor, glicorahiei respectiv clorurorahiei. Efectuarea colorației Gram pentru evidențierea prezenței bacteriilor.

3. Hemocultura şi alte analize de sânge (hemoleucograma completă, respectiv biochimie, serologie).

La pacienții la care exista suspiciunea clinica de hipertensiune intracraniană (tumori sau abcese cerebrale etc.) se efectuează examenul fundului de ochi şi/sau tomografia computerizată înaintea efectuării puncției lombare (4).

Dacă sunt disponibile, tehnicile de investigație moleculară sunt de un real ajutor: multitarget PCR pentru detectarea prezentei bacteriilor patogene în LCR, cu un răspuns rapid în mai puțin de 3 ore (5), iar pentru detectarea enterovirusurilor şi a altor virusuri cu tropism pentru sistemul nervos în mai puțin de 2 ore (5).

\section{MATERIALE ŞI METODE}

Un studiu observațional, aprobat de Comisia de Etică Independentă, a fost desfăşurat la Spitalul Clinic de Boli Infecţioase şi Tropicale „Dr. V. Babeş“ din Bucureşti, în cadrul proiectului de cercetare nr. 35/2014 PN-II-PT-PCCA-2013-4-1836, finanțat de UEFISCDI, în perioada 2014-2017. Au fost încluşi în studiu toți pacienții care s-au prezen- tat la spital cu suspiciunea clinică de meningită si la care s-a obtinut consimțământul informat (pentru copii şi pacienții comatoşi - de la aparţinători).

Criteriile de includere în studiu au fost clinice $(6,7,8)$, epidemiologice şi de laborator (8).

Datele clinice şi paraclinice au fost colectate în sistemul informaţional al clinicii şi în baza de date a proiectului de cercetare, de unde au fost ulterior extrase şi prelucrate statistic cu programul IBM-SPSS statistics v. 20. Variabilele numerice au fost analizate prin $t$-test, iar variabilele categorialele prin testul chi-pătrat. Variabilele numerice sunt exprimate ca medie plus interval de încredere 95\%. Valoarea prag pentru semnificația statistică este $p<0.05$.

\section{REZULTATE ŞI DISCUTुII}

Au fost înrolaţi în studiu 175 de pacienți, dintre care la 78 (44\%) diagnosticul de meningită a fost infirmat, iar la 97 de pacienți (55\%) a fost confirmat. Dintre pacienții diagnosticați cu meningită, 53 (55\%) au avut meningită virală, 31 (32\%) - meningită bacteriană, $12(12 \%)$ - meningită tuberculoasă şi un pacient $(1 \%)$ - meningită criptococică.

În cadrul analizei comparative între grupul reprezentat de cazurile neconfirmate de meningită şi cel al celor confirmate, diferențe semnificative statistic s-au identificat atât la semne şi simptome, cît şi la investigațiile paraclinice ale probelor biologice. Astfel, dintre semne şi simptome, diferențe semnificative statistic s-au înregistrat pentru:

- cefalee: $78 \%$ dintre cei confirmați față de $60 \%$ dintre cei suspicionați clinic şi neconfirmați în urma examenului LCR $(p=0,009)$ şi

- redoare de ceafă: $56 \%$ la confirmați față de $40 \%$ suspiciuni neconfirmate $(p=0,036)$.

Celelalte semne clinice, cum ar fi vărsături, fotofobie şi febră, au fost prezente în proporții aproximativ similare în cele două grupuri (Tabelul 2).

TABELUL 1. Modificările LCR sugestive pentru diagnosticul etiologic al meningitelor.

\begin{tabular}{|c|c|c|c|c|c|}
\hline \begin{tabular}{|l|} 
Cauzele \\
meningitei
\end{tabular} & $\begin{array}{l}\text { Aspectul } \\
\text { LCR }\end{array}$ & $\begin{array}{c}\mathrm{Nr} \text { leucocite } \\
\text { (celule } / \mathrm{mm}^{3} / 10^{6} \text { celule/l) }\end{array}$ & Tipul de celule predominant & $\begin{array}{l}\text { Glucoză în LCR } \\
\text { (normal } \geq 0,5 \text { ) }\end{array}$ & $\begin{array}{c}\text { Proteine }(\mathrm{g} / \mathrm{l}) \\
\text { (normal } 0,2-0,4)\end{array}$ \\
\hline Virală & Limpede & $50-1.000$ & $\begin{array}{l}\text { Mononucleare (pot fi şi neutrofile } \\
\text { în stadiul mpuriu al bolii) }\end{array}$ & normală & $0,4-0,8$ \\
\hline Bacteriană & \begin{tabular}{|c|} 
LCR \\
tulbure sau \\
opalescent
\end{tabular} & $\begin{array}{c}100-5.000 \text { sau peste } \\
5.000\end{array}$ & $\begin{array}{c}\text { Neutrofile } \\
\text { (mononuclearele pot apărea după } \\
\text { an bioterapie sau în faza de debut) }\end{array}$ & $\begin{array}{c}<0,5 \\
\text { Hipoglicorahie }\end{array}$ & $\begin{array}{c}0,5-2 \\
\text { Hiperalbuminorahie }\end{array}$ \\
\hline Tuberculoasă & $\begin{array}{l}\text { clar sau } \\
\text { serocitrin }\end{array}$ & $50-300$ & Mononucleare, monomorfe, mici & $<0,3$ & $0,5-3$ \\
\hline \begin{tabular}{|l}
$\begin{array}{l}\text { Criptococică } \\
\text { (fungică) }\end{array}$ \\
\end{tabular} & clar & $20-500$ & Mononucleare & $<0,5$ & $0,5-3$ \\
\hline
\end{tabular}


TABELUL 2. Caracteristici demografice, clinice şi paraclinice ale pacienților suspicionați/confirmați cu meningită

\begin{tabular}{|c|c|c|c|}
\hline $\begin{array}{l}\text { Variabila } \\
\mathrm{N}=175\end{array}$ & $\begin{array}{l}\text { Suspicionați/infirmați } \\
(n=78)\end{array}$ & $\begin{array}{c}\mathrm{M}\left(\mathrm{b}, \mathrm{v}, \mathrm{mTB}^{*}, \mathrm{mF}^{* *}\right) \\
(\mathrm{n}=97)\end{array}$ & $p$ value \\
\hline Vârsta $(95 \% \mathrm{Cl})$ & $19,04(14,46-23,62)$ & $25,44(20,83-30,06)$ & 0,055 \\
\hline Sexul (M/F) & $44 / 34$ & $50 / 47$ & 0,521 \\
\hline \multicolumn{4}{|c|}{ SEMNE ŞI SIMPTOME } \\
\hline Febră, n (\%) & $54(81)$ & $79(69)$ & 0,060 \\
\hline Cefalee, n (\%) & $47(60)$ & $76(78)$ & 0,009 \\
\hline Redoare de ceafă, n (\%) & $31(40)$ & $54(56)$ & 0,036 \\
\hline Vărsături, n (\%) & $35(45)$ & $43(45)$ & 0,943 \\
\hline Fotofobie, n (\%) & $11(14)$ & $10(10)$ & 0,443 \\
\hline \multicolumn{4}{|c|}{ INVESTIGATIII PARACLINICE } \\
\hline \multicolumn{4}{|c|}{ Analize din LCR } \\
\hline Albumină $(95 \% \mathrm{Cl})$ & $0,181(0,132-0,231)$ & $0,964(0,693-1,236)$ & $<0,001$ \\
\hline Glicorahie $(95 \% \mathrm{Cl})$ & $1,621(0,275-3,519)$ & $0,811(0,291-1,330)$ & 0,374 \\
\hline Clorurorahie $(95 \% \mathrm{CI})$ & $7,291(7,198-7,384)$ & $7,203(7,080-7327)$ & 0,267 \\
\hline Proteine totale $(95 \% \mathrm{Cl})$ & $0,313(0,233-0,394)$ & $1,569(1,125-2,013)$ & $<0,001$ \\
\hline Elemente $(95 \% \mathrm{Cl})$ & $35,99(1,73-73,70)$ & $2924,8(1039,3-4819,3)$ & 0,007 \\
\hline Reacția Pandy (95\%Cl) & $0,28(0,08-0,48)$ & $2,35(2,00-2,70)$ & $<0,001$ \\
\hline Procent PMN (95\%Cl) & $4,00(4,52-12,52)$ & $54,46(44,74-64,18)$ & 0,007 \\
\hline \multicolumn{4}{|c|}{ Analize din sânge } \\
\hline VSH (95\%Cl) & $23,32(16,94-29,70)$ & $31,07(25,38-36,76)$ & 0,074 \\
\hline Leucocite $(95 \% \mathrm{Cl})$ & 9.207 (8.134-10.279) & 12.209 (10.979-13.434) & 0,001 \\
\hline Neutrofile $(95 \% \mathrm{Cl})$ & $6.888(5.970-7.806)$ & $9.663(8.541-10.784)$ & $<0,001$ \\
\hline Limfocite $(95 \% \mathrm{Cl})$ & $1.612(1.358-1.865)$ & $1.653(1.349-1.957)$ & 0,840 \\
\hline Monocite $(95 \% \mathrm{Cl})$ & $655(552-757)$ & $663(566-760)$ & 0,901 \\
\hline Eozinofile $(95 \% \mathrm{Cl})$ & $66(32-99)$ & $35(19-51)$ & 0,079 \\
\hline CRP $(95 \% \mathrm{Cl})$ & $3,87(2,39-5,34)$ & $4,53(2,9-6,1)$ & 0,563 \\
\hline Creatinină $(95 \% \mathrm{Cl})$ & $0,601(0,539-0,663)$ & $0,684(0,607-0,762)$ & 0,114 \\
\hline ALT/TGP (95\%CI) & $29,72(23,35-36,08)$ & $30,74(25,21-36,27)$ & 0,809 \\
\hline Glicemie $(95 \% \mathrm{Cl})$ & $88,51(75,92-101,11)$ & $109,71(96,02-123,40)$ & 0,028 \\
\hline
\end{tabular}

*mTB - meningită tuberculoasă, **mF - meningită fungică

La analiza lichidului cefalorahidian obținut în urma puncției lombare, s-au găsit diferențe semnificative statistic la:

- albumină, cu albuminorahie crescută la cei confirmați față de cei neconfirmați, $0,964 \mathrm{~g} / 1$ față de $0,181 \mathrm{~g} / 1$ cu $p<0.001$,

- proteine totale, $1,569 \mathrm{~g} / \mathrm{L}$ față de $0,313 \mathrm{~g} / 1, \mathrm{cu}$ $p<0,001$,

- elemente nucleate: $2.954,8 / \mathrm{ml}$ față de 35,99 $/ \mathrm{ml}, p=0,007$,

- reacția Pandy: 2,35 față de 0,28, $p<0,001$ şi prezența polimorfonuclearelor în procentaj crescut 54,46\% față de doar 4,00\%, $p=0,007$.

La analizele efectuate pe probele de sânge, valori diferite semnificative statistic s-au constatat pentru:

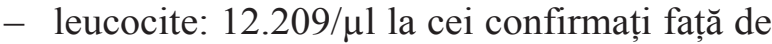
9.207/ $\mu 1$ la cei neconfirmați, $p=0,001$

- polimorfonucleare neutrofile: $9.663 / \mu 1$ la cei confirmați față de $6.888 / \mu 1$ la cei neconfirmați, $p<0,001$
- glicemia: $109,71 \mathrm{mg} / \mathrm{dl}$ la cei confirmați față de $88,51 \mathrm{mg} / \mathrm{dl}$ la cei neconfirmați, $p=0,028$.

Celelalte aspecte sangvine investigate nu au prezentat diferențe semnificative statistic (tabelul 2).

La analiza statistică comparativă a variabilelor grupate în funcție de etiologia meningitei, meningită bacteriană sau meningită virală, s-au găsit diferențe semnificativ statistic atât la caracteristicile demografice (vârstă), cât şi la caracteristicile LCRului şi ale sângelui analizat. Nu s-au găsit simptome şi semne clinice care să difere semnificativ statistic în cele două subgrupuri (Tabelul 3).

Astfel, dintre variabilele demografice, media de vârstă a pacienților cu meningită virală a fost 16,57 ani față de 36,61 ani la pacienții cu meningită bacteriană, $p<0,001$.

La analiza LCR-ului:

- albuminorahia a fost mai crescută semnificativ în meningita bacteriană 1,705 g/l comparativ cu $0,541 \mathrm{~g} / 1 \mathrm{cu}$ meningită virală $(p<$ $0,001)$, 
- proteinele totale $2,854 \mathrm{~g} / \mathrm{l}$ în meningita bacteriană față de $0,839 \mathrm{~g} / 1$ în meningita virală $(p<0,001)$,

- reacția Pandy 3,68 la meningita bacteriană comparativ cu 1,42 la meningita virală, respectiv

- procentul polimorfonuclearelor în meningită bacteriană a fost $76,48 \%$ față de $33,12 \%$ la meningită virală, valoarea $p$ fiind la cele două $<0,001$

- glicorahia a fost mai crescută în meningita virală față de meningita bacteriană $(0,662$ g/l faţă de $0,457 \mathrm{~g} / 1, p<0,001)$.

Analizele sangvine au prezentat un tipar de valori mult crescute (chiar şi de peste 9 ori) la proteina $\mathrm{C}$ reactivă (CRP) pentru pacienții cu meningită bacteriană comparativ cu pacienții cu meningită virală (Tabelul 3).

Astfel, viteza de sedimentare a hematiilor (VSH) a avut valoarea medie $46,04 \mathrm{~mm} / \mathrm{h}$ la paci- enții cu meningită bacteriană comparativ cu 19,33 $\mathrm{mm} / \mathrm{h}$ la cei cu meningită virală $(p<0,001)$ numărul de leucocite a fost $16.654 / \mu 1$ la pacienții cu meningită bacteriană față de $9.984 / \mu \mathrm{L}$ la cei cu meningită virală, $p<0,001$. De asemenea, se disting valori crescute la CRP, creatinină şi neutrofile, diferențele având semnificație statistică mare $(p<0,001)$. Creşterea creatininei, observată la momentul diagnosticului, poate fi explicată de deshidratarea secundară febrei asociate.

\section{DISCUŢII}

În urma analizei comparative se constată că există diferențe semnificative statistic în ceea ce priveşte manifestările clinice (semne şi simptome) respectiv valorile investigațiilor de laborator în grupul pacienţilor care s-au prezentat la spital şi au fost infirmați de meningită față de cei care au fost confirmați ulterior. Astfel, se constată că $40 \%$ din-

TABELUL 3. Caracteristici demografice, clinice şi paraclinice ale pacienților în funcție de etiologie: meningită bacteriană sau meningită virală (cazurile de meningită tuberculoasă şi meningită excluse din analiză deoarece sunt în număr mic)

\begin{tabular}{|c|c|c|c|}
\hline Variabila $\mathrm{N}=84$ & $M B(n=31)$ & $M V(n=53)$ & P value \\
\hline Vârsta $(95 \% \mathrm{Cl})$ & $36,61(28,23-45,00)$ & $16,57(11,28-21,85)$ & $<0,001$ \\
\hline Sexul (M/F) & $17 / 14$ & $29 / 24$ & 0,991 \\
\hline Durata de internare $(95 \% \mathrm{CI})$ & $15,58(12,57-18,59)$ & $11,72(10,75-12,68)$ & 0,004 \\
\hline \multicolumn{4}{|c|}{ SEMNE ŞI SIMPTOME } \\
\hline Febră, n (\%) & $29(93)$ & $41(77)$ & 0,055 \\
\hline Cefalee, n (\%) & $22(71)$ & $45(85)$ & 0,125 \\
\hline Redoare de ceafă, n (\%) & $23(74)$ & $28(53)$ & 0,053 \\
\hline Vărsături, n (\%) & $10(32)$ & $27(51)$ & 0,096 \\
\hline Fotofobie, $\mathrm{n}(\%)$ & $3(10)$ & $6(11)$ & 0,814 \\
\hline \multicolumn{4}{|c|}{ INVESTIGAȚII PARACLINICE } \\
\hline \multicolumn{4}{|c|}{ Analize din LCR } \\
\hline Albumină $(95 \% \mathrm{Cl})$ & $1,705(1,091-2,319)$ & $0,541(0,251-0,831)$ & $<0,001$ \\
\hline Glicorahie $(95 \% \mathrm{Cl})$ & $0,457(0,347-0,567)$ & $0,662(0,604-0,719)$ & $<0,001$ \\
\hline Clorurorahie $(95 \% \mathrm{Cl})$ & $7,27(7,07-7,48)$ & $7,16(6,99-7,33)$ & 0,492 \\
\hline Proteine totale $(95 \% \mathrm{Cl})$ & $2,854(1,789-3,918)$ & $0,839(0,426-1,251)$ & $<0,001$ \\
\hline Elemente $(95 \% \mathrm{Cl})$ & $5.951(2.594-9.308)$ & $1.725(1.058-4.508)$ & 0,058 \\
\hline Reacția Pandy $(95 \% \mathrm{Cl})$ & $3,68(3,29-4,06)$ & $1,42(0,99-1,84)$ & $<0,001$ \\
\hline Procent PMN (95\%Cl) & $76,48(65,50-87,46)$ & $33,12(21,08-45,15)$ & $<0,001$ \\
\hline \multicolumn{4}{|c|}{ Analize din sânge } \\
\hline VSH (95\%CI) & $46,04(33,98-58,10)$ & $19,33(15,37-23,29)$ & $<0,001$ \\
\hline Leucocite $(95 \% \mathrm{Cl})$ & $16.654(14.267-19.040)$ & $9.984(8.992-10.976)$ & $<0,001$ \\
\hline Neutrofile $(95 \% \mathrm{Cl})$ & $14.131(11.838-16.423)$ & 7.486 (6.592-8.379) & $<0,001$ \\
\hline Limfocite $(95 \% \mathrm{Cl})$ & $1.674(1.065-2.284)$ & $1.643(1.297-1.991)$ & 0,925 \\
\hline Monocite $(95 \% \mathrm{Cl})$ & 765 (598-931) & $564(445-682)$ & 0,046 \\
\hline Eozinofile $(95 \% \mathrm{Cl})$ & $20(0,32-39,61)$ & $38(13,11-62,33)$ & 0,308 \\
\hline CRP $(95 \% \mathrm{Cl})$ & $11,49(7,51-15,47)$ & $1,23(0,58-1,87)$ & $<0,001$ \\
\hline Creatinină $(95 \% \mathrm{Cl})$ & $0,960(0,80-1,11)$ & $0,527(0,45-0,60)$ & $<0,001$ \\
\hline ALT/TGP (95\%CI) & $34,97(26,24-43,69)$ & $23,78(19,91-26,09)$ & 0,002 \\
\hline Glicemie $(95 \% \mathrm{Cl})$ & $141,02(108,75-173,29)$ & $96,49(81,50-111,49)$ & 0,005 \\
\hline
\end{tabular}


tre semne şi simptome diferă, cefaleea şi redoarea de ceafă rămânând semne distinctive, rezultat concordant cu literatura (4). La cazurile confirmate de meningită, la analiza pe subgrupe, meningita bacteriană față de meningita virală, semnele şi simptomele nu mai prezintă un tipar distinctiv pentru un grup sau celălalt.

La analiza LCR-ului, 5 dintre cei 7 parametri (71\%) sunt modificați, la grupul bolnavilor de meningită acest aspect indicând şi confirmând încă o dată (9) că LCR-ul este produsul biologic de primă importanță care ajută la stabilirea diagnosticului de meningită.

De asemenea, parametrii LCR-ului sunt indicatori rapizi şi siguri de discriminare (sau diferențiere) între o meningită bacteriană şi o meningită virală deoarece, după cum indică studiul nostru, există diferențe semnificative statistic la 5 dintre cei 7 parametri analizați.

Analiza valorilor constantelor sangvine nu a indicat diferențe relevante între pacienții infirmaţi şi cei confirmați de meningită, doar 3 (30\%) dintre cei 10 parametri prezentând valori crescute la grupul celor confirmați, valori concordante cu literatura (10).

Valorile sangvine diferă la $8(80 \%)$ dintre cei 10 parametri investigați atunci când s-au comparat subgrupurile de meningită bacteriană cu meningită virală, valorile fiind mult crescute în meningita bacteriană.

Menționăm că, în cadrul proiectului de cercetare finanțat prin platforma UEFISCDI, pe lîngă studiul meningitelor prezentate la spital în perioada 20142017, s-a urmărit şi identificarea unor factori clinici (semne şi simptome) şi paraclinici (analize de laborator) maximum predictivi pentru punerea unui diagnostic rapid, care să ghideze atitudinea adecvată ulterioară în cel mai scurt timp posibil, mai ales în secțiile şi unităţile clinice care nu au specificitate de boli infecțioase şi facilitatea de laborator anexată cu funcționare în regim de permanență.

\section{CONCLUZII}

- Examenul LCR este un element-cheie în diagnosticul de meningită şi în diferenţierea etiologiei virale sau bacteriene a meningitelor;

- În meningitele bacteriene, parametrii sangvini ai inflamației au valori net crescute față de cele din meningitele virale.

\section{LIMITĂRI}

Rezultatele studiului nu pot fi extrapolate la eşantioane mai mari sau la populaţia generală de bolnavi de meningită, deoarece se bazează pe un număr relativ mic de cazuri prezentate într-un singur centru clinic.

\section{PERSPECTIVE}

Introducerea unui algoritm sau dispozitiv medical poate să ghideze - cu o acuratețe mare şi rapid - diagnosticul de meningită acută şi diferențial între meningitele bacteriene şi meningitele virale, evitându-se efectele negative ale întârzierii diagnosticului de certitudine şi astfel să se instituie cât mai rapid tratamentul antibiotic util în meningita bacteriană şi inutil în meningita virală. 